\title{
THE CORPORATION AS A TECHNIQUE OF INTERNATIONAL ADMINISTRATION*
}

\author{
Sigmund TIMrekg $\dagger$
}

$\mathrm{T}$ HE MOST DYNAMIC AND SERVICEABLE CONCEPT in the portfolio of modern business, the idea of the corporation, traces its lineage directly back to a great thirteenth century canonist, Pope Innocent IV. During an incubation period of four centuries, the corporate concept was in large measure the handmaiden of institutionalized religion. ${ }^{1}$ It was the legal device whereby a small collective enterprise devoted to God, learning or charity, such as an abbey or university, could preserve its continued existence, its legal rights, and its properties, even though the original human members of the group enterprise had all died.

In the seventeenth century, a new and more ambitious field was carved out for corporate action. The economic exploitation of the wealth to be found in the new hemisphere of the Americas and the old continent of Asia became the province of compact and aggressive groups of merchant adventurers collectively organized as an English (or Dutch, or Portuguese) East India (or a Hudson Bay, or a Muscovy) Company. These companies, in addition to their monopoly privileges and (shall we say sovereign?) immunities from import and export laws and customs duties, had the power to tax their own members, decide their own disputes, and defend themselves against pirates and other external enemies. The English East India Company, it may be noted, not only remained on to subsidize Charles Lamb, John Stuart Mill, and a number of great Orientalists, but ruled India with an iron grip until the middle of the nineteenth century. ${ }^{2}$ In fact, the maintenance of fortifications and consular agents and

* This article represents a considerable expansion of a paper prepared for the Eleventh Conference on Science, Philosophy, and Religion, which took place from September 5th to 8th, 1950. The original paper has just appeared as part of Bryson, Finkelstein, Lasswell and MacIver, Foundations of World Government: A Political and Cultural Appraisal (1952). The views herein expressed are, of course, personal to the author, and are not intended to reflect any governmental or official policies.

$\dagger$ United Nations, Department of Economic Affairs.

${ }_{1}^{1}$ See Goebel, Cases and Materials on the Development of Legal Institutions 547 et seq. (1937); Maitland, The Corporation Sole, 16 L.Q. Rev. 335 (1900), reprinted in Maitland, Selected Essays 73-103 (Hazeltine, Lapsley and Winfield ed., 1936); Dewey, The Historic Background of Corporate Legal Personality, 35 Yale L.J. 655 (1926). Cf. Figgis, Churches in the Modern State (1914).

2 James Mill, the father of John Stuart Mill, wrote, on company time, a voluminous History of British India (1840-48), which is largely a history of the East India Company. It is 
the governmental functions of these trading companies justified their existence even after their economic functions had terminated. ${ }^{3}$

Since that time, the corporate concept has embarked on its third and most inclusive phase. It is no longer the special vehicle for difficult economic undertakings of major public importance. It has become the generally accepted method of conducting all private business enterprises. In fact, it has, in recent years, in the form of government corporations and authorities, such as the Tennessee Valley Authority, the Reconstruction Finance Corporation (and its various special purpose subsidiaries), and regional and local port and transportation authorities, been handling more and more of this country's governmental business undertakings.

On the international front, private business has taken full advantage of this third metamorphosis of the corporate concept. The Hudson Bay and East India trading companies of Elizabethan and Georgian times have been replaced by modern international combines such as N.V. Phillips, Unilever, and International Telephone and Telegraph. On the other hand, national governments have made almost no use of the corporate device in their handling of affairs that call for multi-national action and cooperation. ${ }^{4}$ Effective use of the corporate instrumentality has clearly been a source of strength to the private international combine. Perhaps greater use of it as a medium for international cooperation will serve to counteract, and put sterner administrative fibre into, the disorganized way in which the countries of this world are grappling with international economic affairs.

Furthermore, failure to use the corporate device places national governments at numerous and decided disadvantages in dealing with private international combines. Both in the past and in the present, the organized pursuit of God and the organized pursuit of private gain have had one thing in common; they were free of hampering territorial limitations. A similar freedom from the confinement of geographic boundary lines is not true, however, of the organized pursuit of personal and political security,

interesting to note how much of this History is devoted to dynastic and other political involvements and how little to economic information. For a short account of the outstanding contribution made by East India Company administrators to linguistic research, see Arberry, British Orientalists (1943).

${ }^{3}$ See 8 Holdsworth, History of English Law 200 et seq. (1937).

4 Government corporations have been effectively used by individual national governments to carry out their own international programs, as witness our own Export-Import Bank (in its financing of international loans), the United States Commercial Company (with its wartime financing of preclusive purchasing of critical and strategic materials) and other similar organizations. 
responsibility for which is currently centered in the national state. Both the Papacy, now as in the thirteenth century, and a modern international business combine, together with the spiritual and business affairs confided to their respective ministrations, are integrated globally whereas the national government and its affairs are integrated only up to the national boundary lines. Any objective that a nation wishes to pursue beyond its territorial borders, such as a tariff or customs accommodation, involves either a clash, a negotiation, or a concordat with other sovereign powers. On the other hand, if the management of an international combine in country A desires a branch or subsidiary in country B to open a new factory or change the design of a product, written correspondence, oral instructions, or at the most a stockholder vote, will serve to translate the desire into effective corporate action, at least to the extent that any country adheres to the "liberal" theory with respect to foreign corporations.

Contrasted with the cohesion of business and spiritual units, the organized pursuit of peace and political security is still an internationally splintered affair, based on the teetering and momentary equilibria of jarring national policies and aspirations. The questions raised by this article are: Can the corporate concept, which has had demonstrable utility in stabilizing and internationalizing religion and the day-to-day conduct of business, promote the continuity of international political organization? Can it help accomplish the integration of the international political community? Can it be a democratic and acceptable vehicle for the relief of international tension and strife?

Before attempting an answer to these questions, however, it seems desirable to protest and discard the sterile distinction, first drawn in the second half of the nineteenth century, between politics and economics. For Adam Smith as for Aristotle, political economy had been a philosophically unified discipline; the individual, the household, and the state all had their respective roles in the creation and distribution of wealth. With the devel-

5 The international combine must, of course, follow national policies with respect to the use of local labor, the employment of local capital, the export of dividends, and the like-when the national government is minded to impose such policies. Furthermore, there are difficulties in the way of a single government enforcing its policies against an international combine, difficulties which will be apparent to anyone familiar with the failure of state "blue sky" legislation to cope with fraud in the interstate distribution of corporate securities and of state antitrust laws to stem the national tide of industrial monopoly. Until adequate international instruments for the control of international business units are found, national policies with respect to such units are bound to be frustrated, and the substance of sovereignty in the economic sphere will be with the private corporation, not the State. The legal, economic, and administrative reasons underlying this inability of national states to cope with international combines are set forth in considerable detail in the author's International Combines and $\mathrm{Na}$ tional Sovereigns: A Study in Conflict of Laws and Mechanisms, 95 U. of Pa. L. Rev. 575 (1947). 
opment of laissez-faire economic philosophy, designed to eliminate or minimize the state's role in the wealth-creation and distribution process, and a growing trend toward intellectual specialization and curricular disintegration, political science and economics were cloven asunder. Political analysis was deprived of its material substratum, the economic activities and motives which consume the bulk of the time and energies of most citizens of the political state. Economic description was stripped of the statement of ends, final causes, and values that constitute the raison d'être of political, as of ethical, analysis. ${ }^{6}$ In these days of state economic regulation, state socialism, and state trading, the attempted intellectual divorce between politics and economics, never at any time put into practice, is especially incongruous.

England, Holland, and the other great trading powers of the seventeenth and eighteenth centuries were delegating political power to their foreign merchants, when they permitted those merchants to engage-collectively and under the corporate aegis -in foreign trade. In Maitland's classic phrase, there were "the companies that became colonies, the companies that make war." The same proposition holds for the modern large corporation. The modern state undeniably delegates political power to large private corporations, as it does to the large labor unions with which the corporate behemoths deal. ${ }^{8}$ The authorization of collective activity has, at least since the time the early Christian and Jewish communities had their difficulties with the Roman Emperors, always been a state prerogative. Furthermore, the activities authorized for a large corporation involve such functions as price-fixing, the division of markets, the setting of wages, and the general development of local communities, functions which in a pre-Industrial Revolution era had been the primary responsibility of the State. It has been said of international cartels that some of the more powerful of them "are little empires in themselves, and-their decisions are often more important than those of 'sovereign, political' entities like Holland, Denmark or Portugal." The same could be said even more forcefully of the political strength of that more cohesive unit, the interna-

"An exception to this generalization should be made for the so-called "institutionalist" school, e.g., John R. Commons, Thorstein Veblen and Walton Hamilton.

'Maitland, Introduction to, and Translation of, Gierke's Political Theory of the Middle Age, XXVII (1900).

${ }^{8} \mathrm{~A}$ collective bargaining representative "is clothed with power not unlike that of a legislature." Chief Justice Stone in Steele v. Louisville \& N.R. Co., 323 U.S. 192, 198 (1944). See also ibid., 202-203.

${ }^{9}$ Wild, Sanctions of International Commodity Agreements, 30 Am. J. Int. L. 664,665 (1936). See also Edwards, Economic and Political Aspects of International Cartels (1944); Hamilton, Cartels, Patents and Politics, 23 Foreign Affairs 582 (1945). 
tional combine; the notion that international combines and cartels are strong political entities is no longer a monopoly of the intuitively minded economist or political scientist. Judges have described international cartels as instruments of "private regulation,"10 and have called an American subsidiary the "commercial legation" of its British parent." Even the counsel involved in drafting international cartel agreements speak of a trade area as "so-called neutral territory, or to put it another way as 'spoils' belonging to the British and ourselves as allies in the late war."12 Such a consistent use of political terms is more than a mere metaphor; it is a recognition of an underlying reality.

Not every delegation of political power is a delegation of sovereign power, however. That is an important distinction, because the international community is still premised on the supremacy of the sovereign powers of the individual nation-states. The dividing line is that no state delegates sovereign power when it issues a charter of permissive action, (a) to a specified collective group, (b) for limited purposes, (c) for a limited time, (d) under safeguards based upon a careful survey, (e) with unlimited opportunity for observation of the group, (f) with a continuing right of supervision, and $(\mathrm{g})$ with an ultimate right of revocation. In this country, such safeguards characterized ordinary corporate charters, which were originally issued by state legislatures, even after the middle of the nineteenth century. Even now some South American governments still cling jealously to the right to grant individual corporate charters. ${ }^{13}$

Sovereignty is ultimate power, and controlled delegations of authority cannot impair it. Accordingly, corporations do not necessarily dilute the sovereignty of the national state simply by being permitted to perform the broad functions. What broader powers could a corporation have than to handle a nation's credit or its transportation, or to develop vast untapped lands and natural resources? Yet these were established corporate functions when the nationalist state and the doctrine of national sovereignty were in their hey-day. The corporation did not wrest sovereignty from the state until the state, either through lassitude or preoccupation with other

${ }^{10}$ Judge Rifkind, in United States v. Nat'l Lead Co., 63 F. Supp. 513, 526 (S.D. N.Y., 1945), aff'd, 332 U.S. 319 (1947). See also United States v. Timken Roller Bearing Co., 83 F. Supp. 284 (N.D. Ohio, 1949).

11 United States v. U.S. Alkali Export Ass'n (S.D. N.Y.) unreported opinion, decided by Judge Leibell, July 16, 1946.

12 United States v. Tmperial Chemical Industries, Itd., 100 F. Supp. 504 (S.D. N.Y., 1951).

${ }^{18}$ See Eder, Some Restrictions Abroad Affecting Corporations, 11 Law \& Contemp. Prob. 712,714 (1946); Bonsal and Borges, Limitations Abroad on Enterprise and Property Acquisition, 11 Law \& Contemp. Prob. 720 (1946). 
matters (perhaps some would like to call it a process of constitutional development), endowed it with new and more far-reaching attributes. These new attributes were irrevocable immortality, a very large area of immunity from supervision by the state, and an indifference to (at times even a conflict with) the general political objectives of the state. This new type of corporation, mechanically spawned and sponsored with a sublime indifference as to objective and ignorance as to results, cannot serve as a basis for international action, which is an area where national wishes must continuously be consulted. The older type of individually conceived and nurtured corporation, on the other hand, is consistent with national sovereignty, and yet, on its procedural side, it requires only the formality of incorporation by joint agreement.

Thus, two propositions are clear-the corporate form of transacting business need involve no waiver of national sovereignty, and may embrace activities that can properly be characterized as political. Let us now appraise the political potentialities of the international business corporation by a sidelong glance at some of their more recent activities. Thus, for example, some international combines, like I.G. Farben and the big German banks, have been dramatized as spearheads of the economic penetration of foreign countries and as precursors of military aggression. ${ }^{14}$ Others, like the Herman Goering Works and other German steel combines, have been both the consolidators and the beneficiaries of military aggressions. ${ }^{15}$ Still others function as devices for the international division and exploitation of resources-witness the nationally scattered stockholdings of Royal Dutch Shell, Anglo-American Oil Company, and International Nickel. Organized on a broader and more governmental plane, and functioning as the economic janissaries of political alliance, are such entities as the various development corporations which this country has sponsored in Latin America, and the joint corporations organized by Soviet Russia with Rumania and Hungary. ${ }^{16}$ Corporations have also been created for the purpose of dividing business opportunities and markets abroad, such as the jointly owned subsidiaries of du Pont and Imperial Chemical Industries in Canada, Argentina, and Brazil. ${ }^{17}$ Similarly, they may serve to funnel (1945).

$147 \& 10$ Hearings before Senate Subcommittee on Military Affairs, 79th Cong. 1st Sess.

${ }^{15}$ Edwards, Economic and Political Aspects of International Cartels (1944).

${ }^{16}$ See Timberg, Corporate Fictions: Logical, Social and International Implications, 46 Col. L. Rev. 533, 555-57 (1946). 1951).

${ }^{17}$ See United States v. Imperial Chemical Industries, Ltd., 100 F. Supp. 504 (S.D. N.Y., 
in and channel out, on a joint basis, research and technology, as witness the corporate offspring of Standard Oil and I.G. Farben. ${ }^{18}$

Consider also the broad tapestry of economic activities that have been brought under unified international dominion-coal, iron and steel empires, with all their resultant artifacts and attendant shipping; fats and oils, from the peanut oil of West Africa to the whale fisheries off Spitzbergen; chemicals, a single branch of which starts off with the lowly coal tar and burgeons into all the dyestuffs on and off the rainbow; the chemically affiliated empires of oil, tying the liquid resources and the prosperity of Venezuela and Saudi Arabia with road transport in New York and London, and rubber, performing a similar service for Java and the Philippines. Or reflect on the industrial puissance that has made of Singer, Ford, Kodak, and Coca Cola, international descriptive nouns rather than mere commercial names. Confronted with the most challenging and intricate problems of the production, technology, and distribution of industrial commodities, commercial man has devised elaborate and efficient international frameworks of organization. What is lacking on the political side? Why has political man failed?

Political man has been in the custody of a jealous and insecure national state, which, though it has voluntarily delegated religious and economic authority to subsidiary and continuously operating mechanisms, still hinges its international destinies on the intermittent diplomacy of the Foreign Office and the thousand year old institution of the embassy or legation. International economic organization, as a calculated endeavor on the part of the national states, is still an incipient affair, limited to such activities as the International Postal Union, the international control of radio wave-lengths, a slim secretariat coping with such problems as narcotics, white slavery, freedom of transit, double taxation, international copyright-but always from the outside looking in. ${ }^{19}$ Perhaps the specialized agencies of the United Nations will in time broaden this tradition. However, in the absence of a less diplomatic and gingerly approach, those agencies, like the League of Nations agencies that preceded them, bid fair to suffer from a plethora of broad principles and a deficit of specific business. Decision-making in those agencies must be transferred from the

186 Hearings before Senate Committee on Patents, 77th Cong. 2d Sess. (1942).

19 The broadest general surveys of what has been accomplished along these lines thus far are to be found in Symposium on World Organization, 55 Yale L.J. 865 (1946). See also Timberg, An International Trade Tribunal-A Step Forward Short of Surrender of Sovereignty, 33 Geo. L.J. 373, 377-81, 398-99 (1945), for developments in the specific area of international trade and commerce. Institute on World Organization, World Organization, a Balance Sheet of the First Great Experiment (1942). 
outer and slowly revolving periphery of diverse national delegations to the inner and more decisive core of a unified international secretariat.

The international business corporation, unlike the international political agency, does not suffer from lack of activity; but however inclusive the corporation's control over its own members and its particular segment of the international economy it cannot single-handed accomplish its own integration with other segments of that economy, which are still organized on nationalist lines. Furthermore, the goal of economic security it holds out for its relatively few members is only a fractional answer to the political security that is the goal of organized human society. But the corporate frame of organization supplies a mechanism for getting things done, and this is what international society needs.

Let us distinguish the corporate mechanism for the transaction of international business by a group of private persons from that same mechanism as applied to the conduct of joint governmental operations, by calling the latter an "international govcorp." The question then suggests itself: Where, in the tangled maze of international affairs, would international govcorps make their most effective contribution? In the writer's mind, the most fertile field for the operation of international govcorps are those economic activities which are basic to the prosperity of two or more national communities and which are already subject to some measure of regulation or control by those communities. Characteristically, though, the control exercised by the individual national community is hobbled, and sometimes completely nullified, by territorial boundaries and by the conficting policies of neighboring sovereigns. Those economic activities, to attain their fullest development and promise, desperately require an underlying uniformity of approach and some measure of administrative coordination which can be achieved, without at the same time producing an undesirable inflexibility of operation, by the discriminating use of international govcorps.

Concretely, the international govcorp could, for example, take over the direction of programs for the irrigation, navigation control, and hydroelectric development of international river basins, along the lines of our own Tennessee Valley Authority. Enterprises of this type have already been suggested for the Danube and the Jordan..$^{20}$ In fact international law precedents have been operative for a century in the form of commission regulation of the navigation, commerce and hydroelectric development of

${ }^{20}$ Lowdermilk, Palestine, Land of Promise 171 et seq., 196 et seq., 201, 220, 222 et seq., 230 et seq. (2d ed., 1949); Basch, A Price for Peace 116-18 (1945); Lorwin, Postwar Plans of the United Nations 150 (1943). 
various so-called "international" or "common" waterways. 21 "Experience has shown that special river commissions, each with its powers and duties laid down in an appropriate convention, are a more suitable method of regulating the use of rivers than a general law of rivers could ever be." ${ }^{22}$ There is quite a gap, of course, between the operation of the type of international commission that has been regulating navigation along the $R$ hine or Danube, and an international govcorp charged with the development of an entire region. Nevertheless these international river bodies illustrate the close interdependence between effective international organization and a sound functional operating base.

A well-conceived and properly implemented international river basin authority would be more than a happenstance globalization of our domestic TVA concept. It would be more than a way of establishing the new planner's paradise. It would reflect the statesmanlike concept that people who are working together on functional problems of the highest significance, and on functional regional lines which must necessarily transcend national boundaries, will tend to become immune from sterile national passions and conflicts.

Adoption of the corporate mechanism would infuse, in an area where continuity and harmony of policy are necessary, cooperative procedures of international scope. If enough phases of international economic activity can thus be made the object of dispassionate technical administration and overriding international economic direction, less room would be left for the boundary disputes and ethnic antagonisms that still lie at the root of so much international strife.

The exigencies of conducting World War II produced a unified and cooperating top military command, which issued basic directives and delegated authority down the line without regard to the nationality of the individuals who either laid down or executed the delegations. Supplementing the military decisions, were civilian administrative decisions involving stupendous and delicate assignments and allocations of raw materials, shipping, and industrial resources. Such decisions were not, and could not be, made in the style of conventional diplomacy, one Foreign Office languidly negotiating a treaty with another. The precariousness of the cur-

${ }^{21}$ The best known of the international rivers thus subject to control by international commission are the Rhine, Elbe, Danube, Rio Grande and Colorado, but many lesser rivers and lakes are similarly regulated. It may be noted incidentally in this connection that, while the Suez Canal is nominally an Egyptian joint stock company, there was little doubt, at least until recently, as to its international nature, dominated as it was by the English, French and Egyptians. See Wilson, The Suez Canal (2d ed., 1939).

22 Brierly, The Outlook for International Law (1944). 
rent peace has left the Western Allies with a good deal of this ad hoc, shirt-sleeve collaboration on a direct military basis. Does not that same precariousness press upon Western Europe the drastic need for collective economic-political action along efficient and administrative lines, and the scrapping of the outmoded diplomatic process? In fact, is not the Schuman plan for a unified Ruhr iron and steel economy a belated recognition of that need?

The Council of Europe is, of course, the most advanced current symbol of the need and desire for the political and economic integration of Western Europe. On August 26, 1950, its Consultative Assembly addressed a Recommendation to the Committee of (European) Ministers, in which it expresses the view that the development of insufficiently utilized resources and other activities of the nature of European public utilities might be carried out through agencies or companies established by the Member States in common, jointly financed by them with or without the aid of private capital, and given concessions and regulations by the said states in common. ${ }^{23}$

The Recommendation for the formation of such intra-European govcorps stemmed from a report made by its Committee on Economic Questions, which suggested as appropriate subject matters for such govcorps the following: (1) The hydro-electric development of the Alps. (2) The expansion of colonial production, particularly in Africa. (3) The production of synthetic gasoline, the refining of crude oil, and the distribution of oil and gasoline. (4) A European Bank for Investments. (5) Aviation transport. (6) The securing, for newly tapped sources of production, of a guaranteed market, along the lines of buffer stock agencies known to students of international commodity agreements. (7) The provision of technical assistance. $^{24}$

It would appear that the Council of Europe, while not abandoning its efforts to accomplish the all-out political integration of Western Europe, is focussing on the more tangible and readily digestible projects of setting up functional corporate organisms to do functional jobs. All the suggested activities were already in one way or another the subject of national and international planning and action; what is significant is the suggestion of the new govcorp form, and the implicit dissatisfaction with the prior more diffuse, more feeble, and less governmentally responsive forms of organizational cooperation.

Thus, there have already been both private holding companies, such as

${ }^{23}$ Council of Europe, Consultative Assembly, Document 106, Ordinary Sess. (1950).

${ }^{24}$ Council of Europe, Consultative Assembly, Documents $22 \& 30$, First Ordinary Sess. (1949). 
Sofina, controlling electric utility enterprises in many different countries, and numerous intergovernmental compacts governing the administration of the hydroelectric resources of common rivers. England has had its fiasco of an African "ground nuts" program, a disastrous legacy to a socialist government from the Unilever combine. The international petroleum trade is the domain of a few tremendous private industrial combines, held together by a private concordat that is already the subject of criticism by the consumers of oil. ${ }^{25}$ In the field of new investment, there have been the activities of strong private banking groups, such as the French Banque de l'Indo-Chine (in Indo-China) and Banque Européenne de Pays-Bas (in Africa); the International Bank is, of course, already organized along corporate administrative lines. International air transport is, in almost every country of the world, either a governmental or a private monopoly: the Scandinavian governments have formed a single company for the operation of airlines traversing their territories; there are international conventions and protocols which govern air transport operations; and even in these United States there has been proposed the idea of a single consolidated international airline carrier, or "flag line." ${ }^{26}$ Buffer stock plans have been established, and have broken down, for coffee, rubber, tin, etc., and the commercial aspects of this country's stockpiling of critical and strategic materials from abroad have been entrusted to government corporations. Finally, this nation's Point IV program has attempted to broaden pre-existing private business efforts to help the Western European and other non-Soviet countries bolster their production resources by sparking their technological potential.

The basic reasons that have led these economic wise men of Europe to suggest that these private, uni-national, and diplomatic activities be assigned to the tighter-knit administration of an international govcorp are threefold. First, Europe's increasing awareness of the limitations of its resources (and the consequent necessity for making efficient and economical use thereof) has strengthened the drive for a more compulsive form of international cooperation. A second consideration is the need for developing some instrument for international capital or technological investment that will give the investing country some assurance against unnecessary investment risks, and the country where the investment is made the requisite degree of social control over the joint enterprise-and what more natural

${ }_{25}$ The Oil Business, Report with Recommendations made by the Oil Administration (1945), published by Ivar Haeggstrom Printing Co. (Stockholm, 1947).

${ }^{23}$ Sen. $197 \&$ 987, 80th Cong. 1st Sess. (1947); Sen. 7, 82d Cong. 1st Sess. (1951); H.R. 1,698; 1,$699 ; 2,827 ; 2,828 ; 2,829 ; 2,830,80$ th Cong. 1st Sess. (1947). 
than to adopt the corporate form that had been used for decades by private companies to accomplish similar purposes? And finally, there is a consideration not to be overlooked in the fear-beset world of Western Europe-the fear that such a phenomenon as the reactivation of the Ruhr coal and steel industry will place a perilous industrial (and hence military) potential in the hands of a single (and historically too warlike) nation. It was, in a sense, to bring about a joint military and political control of the industrial potential underlying German rearmament, without pauperizing Europe by depriving it of the valid economic contribution of German industry, that the Schuman Plan was devised. ${ }^{27}$

The international govcorp need not, of course, take the precise shape of a business corporation as the business man or lawyer now knows it. What goes by the verbal tag of "authority" will satisfy the need for efficiency and dispatch quite as well. Furthermore, the secretariat of an international govcorp must be politically adroit and responsive to the unexpressed limits of tolerance of their respective national constituencies. They cannot be allowed to become infatuated with their own blueprints, bemused with their own competence, or satisfied that technical proficiency is their sole warrant for applause or survival. Like Antaeus, an international govcorp will lose its strength when it leaves the ground of political realism. At the same time, it may lose all its social meaning if it becomes too solidly mired in the sticky mud of existing conventional political habits of thought.

The international govcorp will thus doubtless develop characteristics that will differentiate it from the ordinary business corporation. What it will still have in common with such a conventional corporation, however, is efficiency, expeditious mechanisms for airing and reconciling conflicts, and a clearly delineated delegation of authority. Its activity will differ from that of the international diplomatic conference, convention, or committee, in the following respects:

First, the international govcorp will be oriented to the functional administration of a collective enterprise, in which nations will participate on a cooperative rather than an individualistic basis. The focus of the usual international committee or conference is on the anarchic process of diplomatically negotiating differences among the nations as to how each nation will carry out its individual segment of responsibility for what should be a collective enterprise.

Second, the defining of the frame of reference of an international govcorp will be an automatic delegation to its staff of authority to carry out

${ }^{27}$ Discussed at p. 751 infra. 
the agreed-on purposes of the govcorp. The diplomatic techniques of conference, written convention, and committee result at best in blurred halfdelegations to a nation's negotiators, with the necessity for a reference back every time a rival negotiating team initiates a new gambit.

Third, the functions, powers and standards of action of an international govcorp will tend to be concrete and definite, without sacrificing needed flexibility of operation. The corresponding functions, powers, and administrative standards of a diplomatic agreement are necessarily vague and lacking in specificity.

Fourth, the international govcorp will develop plans on an open, empirical, and international basis. Customary diplomatic techniques involve the presentation of preconceived plans, developed in isolation on an a priori, generalized, and rational plane, and enshrouded in the type of secrecy that is inimical to intelligent public comprehension of underlying issues.

Fifth, the conversational technique of the international govcorp is that of the business office-frank, round-the-table discussions. Contrasted to it is the cumbersome technique of the Foreign Office-the interminable and constipated exchange of démarches and pourparlers, drafts and redrafts.

Sixth, the international govcorp will be staffed by an internationallyminded administrative and technical corps. However broad-gauged the international education of Foreign Office officials and however noble their intentions, they carry with them inescapable national and political fetters.

Seventh, the action taken by an international govcorp will be a common decision, based on a proper focusing and funneling of the needed information, policy-making responsibilities, and operational authority. What the international conference approach generates is a welter of national stresses and strains, each based on an improvised and poorly integrated admixture of factual data, general blueprints and principles, and immediate political decisions. Sometimes, this welter emerges in a cloudy compromise, sometimes not.

Let us examine these seven administrative advantages of corporate action over diplomatic action in the light of that recently established international govcorp, the European Coal and Steel Community, otherwise known as the Schuman Plan.

First, what is the collective enterprise? It is the coal and steel industry of six countries, France, West Germany, Belgium, Holland, Luxembourg, and Italy. Hitherto conducted under the separate auspices of six national governments and hence involving an uneasy interdependence among six 
autonomous markets, this industry, by a stroke of international creativeness, attains an integrated "common market" and a measurable degree of international political control..$^{28}$

Second, the general purposes of the Plan are defined in Articles 2 and 3 of the Treaty. ${ }^{29}$

Third, are the plans of this Community specific and concrete? It would seem sufficient here to note the great detail with which are spelt out such functions of the High Authority of the Community within the common market as the approval of new capital investment programs and assistance in their financing (Art. 54); the encouragement of technical and economic research (Art. 55); the attempt to deal with the effects, particularly as they concern employment, of technological innovation and capital expansion (Art. 56); the allocation, "in a period of manifest crisis," of produc-

${ }^{28}$ The High Authority which manages the affairs of the Community has been referred to as a supra-national agency. This, of course, is a highly significant distinction, for it means that High Authority can make decisions which must be obeyed by the national states. While the provisions of the organic treaty of the Community justify this characterization of the High Authority as supra-national, doubt has been expressed as to whether "vital interests" of the contracting nations will in actual operation be subordinated to the decisions of the High Authority. See note 39 infra.

29 "Article 2: The mission of the European Coal and Steel Community is to contribute to economic expansion, the development of employment and the improvement of the standard of living in the participating countries through the institution, in harmony with the general economy of the member States, of a common market as defined in Article 4.

"Community must progressively establish conditions which will in themselves assure the most rational distribution of production at the highest possible level of productivity, while avoiding the creating of fundamental and persistent disturbances in the economies of the member States.

"Article 3: Within the framework of their respective powers and responsibilities and in the common interest, the institutions of the Community shall:

(a) See that the common market is regularly supplied, taking account of the needs of third countries;

(b) Assure to all consumers in comparable positions within the single market equal access to the sources of production;

(c) Seek the establishment of the lowest prices which are possible without requiring any corresponding rise either in the prices charged by the same enterprises in other transactions or in the price-level as a whole in another period, while at the same time permitting necessary amortization and providing normal possibilities of remuneration for capital invested;

(d) See that conditions are maintained which will encourage enterprises to expand and improve their ability to produce and to promote a policy of rational development of natural resources, avoiding inconsiderate exhaustion of such resources;

(e) Promote the improvement of the living and working conditions of the labor force in each of the industries under its jurisdiction so as to make possible the equalization of such conditions in an upward direction;

(f) Further the development of international trade and see that equitable limits are observed in prices charged on external markets;

(g) Promote the regular expansion and the modernization of production as well as the improvement of its quality under conditions which preclude any protection against competing industries except where justified by illegitimate action on the part of such industries or in their favor." 
tion quotas and coal and steel resources (Arts. 58, 59); the prohibition of unfair competitive practices (particularly "price reductions whose purpose is to acquire a monopoly position within the common market") and of discriminatory prices and practices (particularly those based on the nationality of the buyer) (Arts. 60,63); the fixing of maximum and (where "a manifest crisis exists or is imminent") minimum prices (Art. 61); and the forbidding of agreements to fix or influence prices, restrict or control production, technical development or investments, or allocate markets, products, customers or sources of supply (Art. 65). With respect to mergers, corporate acquisitions and other concentrations of business enterprise, the High Authority must pass on all such concentrations, authorize only such concentrations as do not impair the maintenance of effective competition or evade the rule of competition, and split up illegal concentrations (Art. 66). The foregoing are direct responsibilities of this new industrial Community. In addition, there are other duties of this govcorp where the emphasis is to stimulate appropriate national action, in such areas as wages and the movement of labor (Arts. 63, 64), transport (Art. 65), and customs duties (Art. 67).

Fourth, the public and open nature of the Community's operations seems to be insured by two main types of provisions. One is a direct and unequivocal emphasis on publicity (see Art. 5). The other is the rather elaborate system of checks and reviews to which the High Authority, the operating core of the enterprise, is subjected, i.e, the operations of the Consultative Committee, consisting of an equal number of producer, worker, and consumer representatives (Arts. 18, 19); the power of the General Assembly (representing the peoples of the member States) to review the report of the High Authority and bring about the High Authority's removal by passing a motion of censure (Art. 24); the necessity of consulting with the Council, the diplomatic representatives of the member States (Art. 26), which has the power to fix the salaries of the High Authority (Art. 29); and the review jurisdiction of the Court over violations of the Treaty and abuses of power or authority (Art. 33).

The Council acts as a buffer, either by way of consultation or as a body whose concurrence is required, on matters that require harmonizing the actions of member governments, such as the member government's guarantee on loans obtained by enterprises (Art. 51), the institution of financial mechanisms to carry out the objectives of the Community (Art. 53), the financing of programs for the re-employment of displaced workers (Art. 56), the setting up of production quotas (Art. 58), restrictions on exports to third countries (Art. 59, Sec. 5), the fixing of maximum or mini- 
mum prices (Art. 61), and recommendations to States to counteract special advantages given to, or burdens placed on, coal or steel enterprises within their borders (Art. 67). Of special interest is the one situation in which the Council wields direct executive authority (with the High Authority having only proposal-making and consultative functions)-the establishing of consumption priorities and the allocation of coal and steel among the Community's industries (Art. 59). The relegation of the High Authority to a secondary role in connection with this function probably stems from a fear that, being so intimately focussed on the coal and steel industry, it might tend to favor coal and steel enterprises as against other industries that also need coal and steel, e.g., power. The Consultative Committee similarly acts as a buffer, usually along with the Council (Arts. $53,55,58,59,62,67)$ where the favorable opinion of worker, technical and consumer groups plays an important part in assuring the success of the High Authority's operations. It is particularly and uniquely concerned with (1) action where the standard of living of workers drops (Art. 68), and (2) the choice of "abnormal base points" for price quotations (Art. 60 ). It might conceivably be contended that this set of reviews and controls by the diplomatic, democratic, economic, advisory, and judicial organs of the Community indicate an over-wieldy organization, but they clearly seem to be sanctions against the development of visionary, impractical or secretive programs of action.

Fifth, the greater informality of the European Coal and Steel Community over conventional diplomatic bodies is implicit throughout its set-up. In addition, note the ample provision made in the Treaty for the issuing of opinions and recommendations (Art. 14), and the High Authority's power to institute what are quite non-ornamentally labeled economic study groups (Art. 16).

The sixth administrative consideration, the composition of the international secretariat, may well be the most vital ingredient of effective international cooperation. Here it should be noted that the High Authority of the Community, which is charged with the execution of the wealth of functions already described, is to be chosen on the basis of the cardinal considerations of general competence and independence of connection with the industry (Art. 9). Also, it is provided that the Court cannot review the conclusions of the High Authority which are based on economic facts (Art. 33).

Seventh and last, we come to the end result of all this administrative machinery, the making of informed and effective decisions. This is a result that no amount of forceful treaty language or detailed organizational pro- 
cedures can guarantee. However, the Treaty empowers the High Authority, the trained secretariat or executive management committee of the Community, to make binding decisions (Arts. 14 and 15). The publication of opinions and recommendations already alluded to, while on the surface informal and noncommittal, may in certain circumstances have a genuinely compulsive impact. ${ }^{30}$

It is not intended by the foregoing to convey an enthusiastic and unqualified approval of the Schuman Plan. For one thing, it is important not to take the word for the deed. Subsequent operating experience may completely frustrate what is, thus far, a thoroughgoing expression of ambitious international ideals. The lack of a cooperative spirit in the future may defeat the achievement of that climate of cooperation that pervades the letter and the surface of the treaty document. ${ }^{31}$ Furthermore, doubt has been expressed as to whether the Schuman Plan "would be more than a governmental façade for an old fashioned cartel." " Anxiety has been felt that certain allegedly temporary expedients, such as price-fixing and special reconversion funds, designed to facilitate an easier transition to the Europe-wide common market, may turn out to be a permanent (and cartelized) state of affairs. Then, will the French close some of their coal pits, with possible dire unemployment problems, if competitive forces demonstrate that their continued operation is uneconomic? Will the German steel industry keep down production and sacrifice immediate profits, if that be the competitive verdict? ${ }^{33}$

There is possible occasion for other basic criticisms of the philosophy of the entire project, e.g., that it gives undue prominence to the factor of regulation (as contrasted with our own competitive system) or that it does not have sufficient safeguards against control by engineer bureaucrats or financial oligarchs. ${ }^{34}$ The only point relevant to this paper is that six countries have come to grips with a gargantuan economic problem that they had in the past unsuccessfully sought to cope with by other means, and

${ }^{30}$ On publicity as a legal sanction, see Timberg, op. cit. supra note 19, at 390-91.

31 While an impressive juridical panoply has been built up by international convention for the institutions and functionaries of the European Coal and Steel Community, it still remains to be seen how its operations will in practice be geared in to the policies of national sovereign striving to exert a more local, but nevertheless pertinacious, jurisdiction over coal and steel enterprises.

2158 The Economist 1105, 1107 (1950).

as Diebold, Imponderables of the Schuman Scheme, 29 Foreign Affairs 114 (1950).

${ }^{34}$ A defender of the Schuman Plan would perhaps attempt to remind us that our bituminous coal industry has been the subject of extensive regulation by administrative commissions and that despair at eliminating elements of rigidity in the production policies and price structure of the steel industry has brought forth suggestions for governmental administrative control. 
that they have contrived an organizational framework that has some promise of effective (if not necessarily the correct) resolution of that problem.

To those who believe in the ultimate necessity of an all-inclusive international government, there may be something distasteful about the limited coverage of any one international govcorp, such as the European Coal and Steel Community. There may be a disagreeable lack of symmetry in the probable haphazard proliferation of such govcorps. To the writer, however, this limited coverage has certain very practical advantages, and is consistent with the rule of law in the international community.

In a more principled and less empirical stage of my own intellectual development, I remember being somewhat taken aback by the last few pages of Sir Henry Sumner Maine's lucid Lectures on International Law. The bulk of this very readable volume was taken up with a statement of the principles and historical development of international law, particularly the law of belligerency. In his last chapter, Sir Henry turned to the topic of proposals to abate war. After reviewing other proposals and precedents, Maine concluded that the old-fashioned entente of leading powers was the best system for keeping the peace. For him, the most effective historical precedent along these lines had been an informal amicable understanding that had prevailed for ten years among three Emperorsthose of Germany, Russia, and Austria-Hungary.

Now, what is so defective about this so simple solution? It is this: Peace depends on relationships among men, not among governments and their titular heads. "Government" and "emperor" are symbols upon whom, as the focal point of their country's foreign relations, converge and through whom are discharged the outgoing pressures and passions of their respective human components. Governments differ in their potentialities for maintaining peace. That difference is a function largely of whether a monolithic or a pluralistic state is involved, i.e., whether the national government tenaciously clings to control of all the concerns of its citizens, or whether it is prepared to make wise delegations of authority to groups within its borders.

Take, for example, the historical role of England and Germany. As a practical matter, England was a pluralistic state, which had worked out a marked degree of autonomy and responsibility for individuals, for incorporated and unincorporated groups, and even for different segments of its government. Germany, as Thorstein Veblen pointed out, was an absolutistic state two generations removed from feudalism. ${ }^{35}$ England, in the

${ }^{35}$ Veblen, Imperial Germany and the Industrial Revolution (1939). 
sneering language of German imperialists, Karl Marx, and Werner Sombart, was a race of craven and utilitarian shopkeepers, devoted to selfish commercial gain, muddling along with specific enterprises and transactions-and hence addicted to the ways of peace. Germany, on the other hand, in the minds of some of its apologists, was a country of heroic, unselfish, and logical idealists, devoted to grand and heroic conceptions, unambiguously dedicated to national honor and glorification-and hence born warriors. ${ }^{36}$

A pluralistic state (England) tends to make for peace, and a totalitarian state (prewar Germany) for war. Why? Perhaps an analogy may clarify. The external attitudes and relations of a pluralistic state are like an electric transmission grid with many parallel wires and many circuit interrupters and disconnecting switches; those of a totalitarian state are like a system with but a single wire and almost no facilities for stepping down voltages. Voltages which can be comfortably carried by the pluralist system would, in the case of the totalitarian one, cause breakdowns and electrocution of maintenance men. In short, a country needs as many men as possible, not one man, in positions of control of its international affairs. And it needs men with specific competence for specific subject matters, not merely people with a general flair for negotiation. If political pluralism, i.e., the delegation of specific subject matters of common social concern to specially constituted and qualified groups, makes for order, prosperity, and harmony within national states, why should it not do so among those states? If decentralization, i.e., the delegation of specific tasks to the men and industrial units best suited for them, is a necessity for the modern large industrial corporation, may it not also be a crying need of the modern society of nations? So, let us not be afraid of limited coverage for our international govcorps; let us rather fear our human inability to cope with even that limited coverage.

The international govcorp is not going to fragmentize or otherwise jeopardize the rule of international law and order, viewed as a pragmatic reality and not as a set of universal verbal prescriptions. Law's chief sagacity lies in its self-denying nature and the scope and comity it accords to custom, usage, and accepted mores. A society's lawfulness is in inverse proportion to the number of its laws, and the frequency with which its citizens go to court. Therefore, if the international community has mechanisms which can prevent violence and mitigate international tensions, international law prevails. And the international community can mitigate

\footnotetext{
${ }^{36}$ See Armstrong, Thus Speaks Germany 153-56, 159-60, 163-64, 171 (1941); Dewey,
} German Philosophy and Politics 57 (1915); Sombart, Handler und Helden (1915). 
tensions, and avert violence, by providing forums for the discussion and release of such tensions. Preferably, these should be separate forums wherein individual causes of tensions can be aired and worked out.

Thus, the limited coverage of an international govcorp is an advantageous matter for international development and the removal of international friction. Also, a limited charter of activities would serve to satisfy the national states that might be jealous of any broader grant, because such a limitation would conserve for the national state its true sovereignty. It has already been noted that such a limitation helped satisfy national states at a time when they were most sensitive to the encroachments of the private business corporation. ${ }^{37}$

Let us be, therefore, not logical absolutists, but philosophical positivists in the field of international institutions. Rather than wait for the realization of currently unattainable ideals of an international legislature, executive, or judiciary, let us focus on institutions less removed from the dayto-day activities of men. Let us remember that the pax Romana of classical times and the pax Britannica of the nineteenth century were periods, not of grand, unifying juridical ideologies, but of intensified commercial activity accompanied by enough law to settle such commercial disputes as arose. Viewed in such a modest yet not unambitious perspective, international govcorps - if their status and activities can but be geared with those of the existing political sovereigns, the national states ${ }^{38}$-will not retard, but rather promote, the ultimate development of world order, limited though they may be to selected enclaves of international activity. ${ }^{39}$

${ }^{37}$ See p. 742 supra.

${ }^{38}$ See Timberg, International Combines and National Sovereigns: A Study in Conflict of Laws and Mechanisms, 85 U. of Pa. L. Rev. 575, 609 (1947).

${ }^{39}$ Disputes among individuals are the everyday concomitants of their international economic activity. The resolution of those disputes is, therefore, an unobtrusive method of building up international law without derogating from national sovereignty. Accordingly, the author has staked greater hopes for peace among nations on an international trade tribunal, to handle the disputes of individuals, than on a High Court of Justice, to handle disputes among nations. See Timberg, An International Trade Tribunal, 33 Geo. L. J. 373 (1945). 